\title{
Clearance and tissue distribution of staphylococcal enterotoxin $A$ in the rat and potential use of adsorbents for removal from plasma
}

\author{
M. NAGAKI, R. D. HUGHES, HELEN M. KEANE, J. GOKA and R. WILLIAMS*
}

Institute of Liver Studies, King's College School of Medicine and Dentistry, Bessemer Road, London SE5 9PJ

\begin{abstract}
Summary. Many of the profound effects of staphylococcal septicaemia are thought to be the result of entry of enterotoxins into the systemic circulation. The aim of this study was to investigate the disposition of staphylococcal enterotoxin A (SEA) in the rat and its possible removal from blood. SEA labelled with ${ }^{125} \mathrm{I}$ was administered intravenously $(250 \mu \mathrm{g} / \mathrm{kg})$ to rats. The blood clearance of SEA showed a biphasic pattern; an initial fast disappearance (half-life $c .3 \mathrm{~min}$ ) was followed by a slower one (half-life $c .2 \mathrm{~h}$ ). Thirty minutes after injection of ${ }^{125}$ I-labelled SEA, most of the radioactivity was concentrated in the kidneys, indicating that renal excretion was the main route of elimination of SEA. The adsorption capacities of polymer-coated activated charcoal (DHP-1 and Adsorba 150C), uncharged resin (Amberlite XAD-7), anion exchange resin (Dowex-1) and polymyxin B matrix were assessed by measurement of the equilibrium adsorption isotherms for SEA. DHP-1 charcoal, Amberlite XAD-7 resin and Dowex-1 resin adsorbed similar amounts of SEA in human plasma. Plasma perfusion experiments were performed in vitro with small columns containing either charcoal or resin adsorbents. Over $4 \mathrm{~h}$ perfusion, DHP-1 charcoal removed $50 \%$ of the initial amount of ${ }^{125}$ I-SEA, Adsorba 150C charcoal $8.1 \%$ of SEA and Amberlite XAD-7 resin $32.5 \%$ of SEA. These results suggest that it may be feasible to develop the adsorbent columns for direct removal of SEA from the plasma of patients with staphylococcal septicaemia.
\end{abstract}

\section{Introduction}

The exotoxins released by Staphylococcus aureus include enterotoxins (SEs) A, B, Cl-3, D and E, toxic shock syndrome toxin 1 (TSST-1) and staphylococcal exfoliative toxin $(\mathrm{ExFt})$. These toxins are structurally closely related ${ }^{1,2}$ and are known to be responsible for human diseases such as food poisoning, ${ }^{3}$ shock $^{4}$ and scalded skin syndrome. ${ }^{5}$ In mice and monkeys, these toxins produce rapid weight loss and death. ${ }^{6.7}$ Staphylococcal sepsis in man could cause potent enterotoxins to circulate throughout the body, resulting in damaging effects. Studies have been performed in animals to characterise the toxaemia produced by parenteral administration of staphylococcal enterotoxins. Intravenous administration of SEB produced fever and leucopenia followed by leucocytosis and shock. ${ }^{8}$ Shock appeared to develop through pathophysiological mechanisms similar to those which accompany bacterial endotoxaemia, ${ }^{9}$ which is mediated by cytokines released from macrophages or monocytes as a result of stimulation by lipopolysaccharide (LPS) ${ }^{10,11}$ The staphylococcal toxins also increase susceptibility to endotoxic shock, ${ }^{12}$ which may be important clinically.

Received 13 Aug. 1992; accepted 13 Nov. 1992.

* Correspondence should be sent to Dr R. Williams.
The specific mechanisms involved in the toxicity of staphylococcal enterotoxin A (SEA) have been elucidated only recently, in studies which have demonstrated that nearly all of the toxins bind to major histocompatibility complex (MHC) proteins. ${ }^{13,14}$ These complexes of toxin and MHC proteins stimulate $\mathrm{T}$ cells, ${ }^{15,16}$ causing the release of large amounts of cytokines, including tumour necrosis factor (TNF) and $\gamma$-interferon (IFN- $\gamma$ ). ${ }^{17,18}$ These responses are beneficial to the host in small quantities, but damaging in excess. Direct removal of these enterotoxins from the circulation may be of potential therapeutic value in preventing the consequences of staphylococcal septicaemia.

In the present study, the clearance and tissue distribution of SEA was investigated in rats and the capacities of various adsorbents to bind this toxin in vitro assessed with the aim of directly removing the toxin from the circulation.

\section{Materials and methods}

Purified staphylococcal enterotoxin A was provided by the Centre for Applied Microbiology and Research, PHLS, Porton Down, Wilts. Radioactive sodium $\left({ }^{125} \mathrm{I}\right)$ iodide $(100 \mathrm{mCi} / \mathrm{ml})$ was obtained from Amer- 
sham International plc, Buckinghamshire. DHP-1 charcoal, coated with polyhema, was purchased from Kuraray Co. Ltd, Osaka, Japan; Adsorba 150C charcoal, coated with cellulose, from Gambro Ltd, Sidcup, Kent; Amberlite XAD-7 resin (425-850 $\mu \mathrm{m}$ fraction) from Rohm and Haas Ltd, Croydon, Surrey; Dowex-1 resin (50-100 $\mu$ m fraction) from Sigma; and Affi-Prep Polymyxin Matrix from BioRad.

Male Wistar rats (190-200 g) were housed in an airconditioned room with a 12-h light-dark cycle and maintained on a commercial stock diet and tap water ad libitum. For experiments in vitro, SEA was added to citrated human plasma, obtained from four patients with haemochromatosis who were undergoing weekly venesection therapy and who all had normal serum tests of liver function.

\section{Iodination of SEA}

SEA was radiolabelled with carrier-free $\mathrm{Na}^{125}$ I by immobilised lactoperoxidase according to the method of David and Reisfeld. ${ }^{19}$ Briefly, $100 \mu \mathrm{g}$ of SEA in $50 \mu \mathrm{l}$ of pyrogen-free water was mixed with $50 \mu \mathrm{l}$ of azide-free phosphate-buffered saline (PBS), $\mathrm{pH} 7 \cdot 4$, $10 \mu \mathrm{l}$ of $0.1 \mathrm{~mm} \mathrm{NaI}, 25 \mu \mathrm{l}$ of immobilised lactoperoxidase suspension and $10 \mu \mathrm{l}(1 \mathrm{mCi})$ of carrier-free $\mathrm{Na}^{125} \mathrm{I}$. The reaction was started by the addition of $10 \mu \mathrm{l}$ of $1 \mathrm{mM} \mathrm{H}_{2} \mathrm{O}_{2}$ and incubation was for $30 \mathrm{~min}$ at room temperature. The reaction was terminated by diluting the mixture to $0.5 \mathrm{ml}$ with PBS containing sodium azide $0.02 \%$, and the lactoperoxidase was removed by centrifugation at $3500 \mathrm{~g}$ for $3 \mathrm{~min}$. Radiolabelled SEA was separated from the NaI by fractionation on a Sephadex G-50 column and purified by extensive dialysis with PBS. The concentration of SEA was determined by an ELISA specific for SEA with a sensitivity limit of $7.8 \mathrm{ng} / \mathrm{ml}$. This sandwich assay incorporated a guinea-pig polyclonal antibody to SEA on the plate and a rabbit polyclonal second antibody to SEA, both provided by the Centre for Applied Microbiology and Research; detection was with antibody to rabbit IgG conjugated with horseradish peroxidase (Dako). The specific activity of ${ }^{125}$ I-SEA was $220 \mathrm{Ci} / \mathrm{mmol}$.

\section{${ }^{125}$ I-SEA administration to rats}

SEA $\left(50 \mu \mathrm{g}\right.$ containing $2.25 \mu \mathrm{Ci}$ of ${ }^{125} \mathrm{I}$-labelled SEA in $200 \mu \mathrm{l}$ of PBS) was injected as a bolus into the femoral vein of the rats $(n=9)$ over a period of $1 \mathrm{~min}$. Rats were kept anaesthetised throughout the experiment with sodium pentobarbitone. Clearance of SEA was determined from the radioactivity in $100-\mu 1$ blood samples taken at various intervals, starting at $2 \mathrm{~min}$ after injection (three rats were sampled at each time point). Distribution of SEA in tissues was studied in rats killed 5, 30 or 120 min after injection. Whole organs were weighed, and blood, urine and tissue samples were placed into pre-weighed labelled vials, and sample weights were determined. Tissue, blood or urine samples were distributed into plastic tubes and the radioactivity was measured in a $\gamma$ scintillation counter (Canberra Packard). The total amount of SEA in $\mu \mathrm{g} / \mathrm{g}$ of tissue was calculated from ${ }^{125} \mathrm{I} \mathrm{cpm} / \mathrm{g}$ of tissue and the specific activity of the injected SEA. To determine free iodine in blood and urine samples, membrane ultrafiltration was performed in an Amicon Stirred Cell (Amicon Ltd, Upper Mill, Stonehouse) with a PM10 membrane ( 10000 da cut off) as the $M_{r}$ of SEA protein is 27078 . Free ${ }^{125} \mathrm{I}$ present passes through the membrane and is detected in the filtrate.

\section{In vitro binding of SEA}

The two polymer-coated activated charcoals (DHP1, Adsorba 150C), uncharged resin (Amberlite XAD7), anion exchange resin (Dowex-1) and polymyxin matrix (Affi-Prep) were tested for their capacities to bind ${ }^{125} \mathrm{I}$-labelled SEA in vitro. To determine the effects of plasma protein binding of SEA on adsorption, two different media were used: PBS, $\mathrm{pH} 7 \cdot 4$, with bovine serum albumin (BSA) $1 \mathrm{mg} / \mathrm{ml}$ (to prevent adhesion to plastic) and human plasma; $1 \mathrm{~g}$ (wet weight) of the charcoals or resin, or $1 \mathrm{ml}$ of polymyxin matrix $(50 \%$ suspension) was added to $5 \mathrm{ml}$ of the media containing ${ }^{125} \mathrm{I}$-SEA at a concentration of $1,5,10,50,100,500$ or $1000 \mathrm{ng} / \mathrm{ml}$, and mixed on a roller mixer for $48 \mathrm{~h}$ at $4^{\circ} \mathrm{C}$. The supernate was aspirated and assayed for free SEA by measurement of $\gamma$ radioactivity. A sample of the wet charcoal and resin used was dried at $60^{\circ} \mathrm{C}$ to obtain the dry weights of adsorbent used. The binding capacity of each adsorbent was determined from the amount of SEA bound/g of dry adsorbent at equilibrium.

\section{Adsorption characteristics during column perfusion}

Columns $(7.2 \mathrm{~cm}$ length, $2.2 \mathrm{~cm}$ internal diameter) cut from polystyrene tubes (Sterilin, Teddington, Middlesex) were packed with DHP-1 charcoal, Adsorba $150 \mathrm{C}$ charcoal or Amberlite XAD-7 resin. Human plasma containing ${ }^{125}$ I-labelled SEA (100 ng/ $\mathrm{ml}, 11 \mathrm{Ci} / \mathrm{mmol}$ ) was perfused through the columns. The perfusions were performed in a scaled-down recirculating perfusion circuit for $4 \mathrm{~h}$ at a flow rate of $30 \mathrm{ml} / \mathrm{min}$. Plasma was simultaneously sampled from the column inlet and outlet at different time points. The serial concentrations of SEA were determined by measurement of the ${ }^{125} \mathrm{I}$ radioactivity in the plasma samples in a $\gamma$ scintillation counter. At the end of perfusion, the columns were washed thoroughly with saline and samples of the adsorbents were counted to determine directly the amount of the substance bound to the adsorbent.

\section{Results}

Intravenous bolus injection of $250 \mu \mathrm{g}$ of SEA $/ \mathrm{kg}$ body weight was associated with an immediate peak 


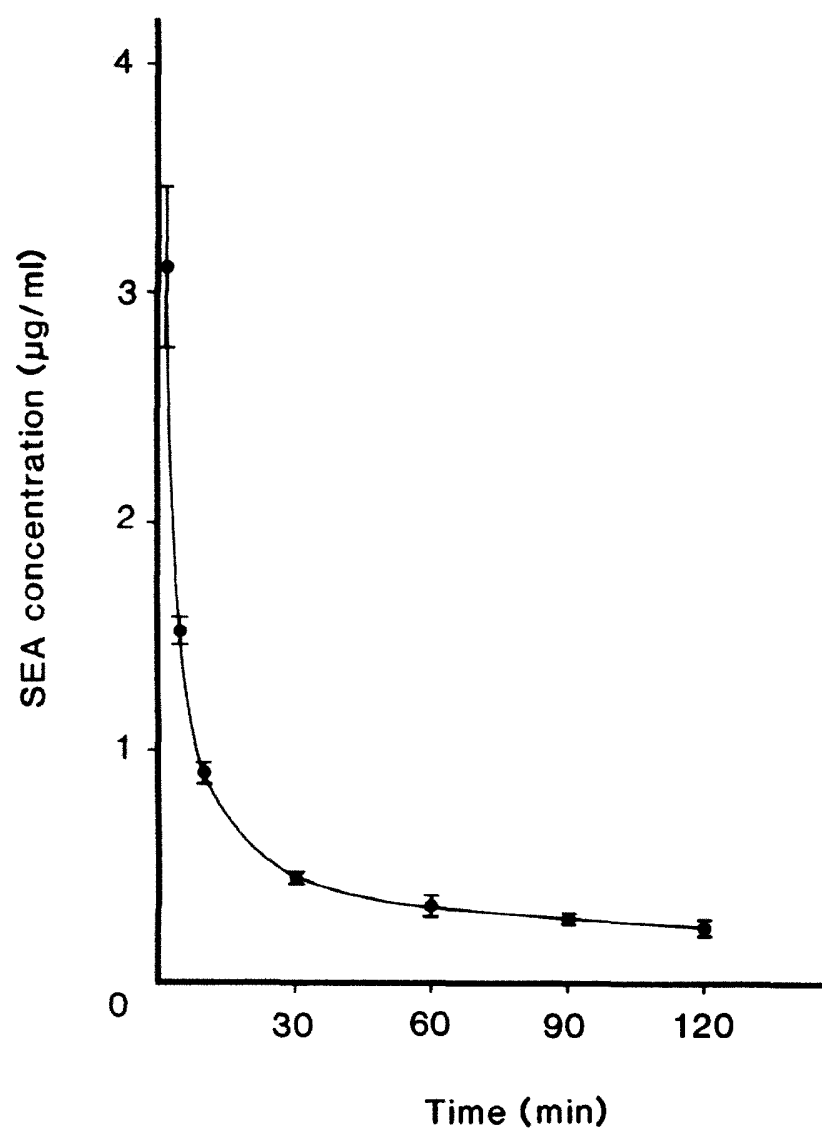

Fig. 1. Concentration of ${ }^{125}$ I-labelled SEA in blood of rats following i.v. bolus injection of SEA $250 \mu \mathrm{g} / \mathrm{kg}$ body weight. Each point represents the mean value and SEM for three to six rats.

and rapid decline in blood concentrations of SEA (fig. 1). The elimination consisted of two exponential components: an initial fast one with an average halflife of c. $3 \mathrm{~min}$ and a second slower one with a half-life c. $2 \mathrm{~h}$. To determine whether the radioactivity detected in blood was associated with SEA, plasma samples obtained $30 \mathrm{~min}$ after injection of the dose were ultrafiltered; $<4 \%$ of the radioactivity was ultrafiltrable through a PM 10 membrane, indicating that most of the radioactivity in blood was still associated with SEA.

Measurement of the time course of the distribution of tissue radioactivity within different tissues following the i.v. injection of ${ }^{125}$ I-labelled SEA showed that the greatest concentration of radioactivity/g wet tissue weight was found in the kidney at all time points (table I). Comparison of the concentration of SEA in tissue (uncorrected for blood contamination) with the concentration of SEA in blood at 30 and 120 min showed that SEA was at significantly higher concentrations in the kidney and spleen than in blood. The concentrations in other tissues and organs (liver, lung and muscle) were equal to or less than that in blood. On a whole organ basis, at $5 \mathrm{~min}$, the liver accounted for $16 \%$ of the injected dose of radioactivity, kidney $8 \%$ and spleen $1 \%$, at 30 min liver $8 \%$, kidney $36 \%$ and spleen $2 \%$, and at 120 min liver $6 \%$, kidney $20 \%$ and spleen $2 \%$. A large amount of ${ }^{125}$ I-labelled SEA was observed in urine at 30 and $120 \mathrm{~min}$. Ultrafiltration with a PM 10 membrane showed that $>70 \%$ of radioactivity excreted in the urine appeared to be still associated with SEA. Significant amounts of ${ }^{125} \mathrm{I}-$ labelled SEA were also found in the duodenum at $2 \mathrm{~h}$, which indicates the possibility that ${ }^{125}$ I-SEA was excreted into bile.

\section{Effects of adsorbents on removal of SEA}

All adsorbents tested except for the polymyxin matrix adsorbed SEA. The polymyxin matrix, which has a specific affinity for LPS, did not bind any SEA from either PBS solution or human plasma. For the other adsorbents, a higher affinity for adsorption of SEA from PBS solution was found than from human plasma (figs. 2a and 2b). Comparing the binding abilities of the different adsorbents for SEA, the rank order of amount bound/g of dry adsorbent in PBS solution was: DHP-1 charcoal $>$ Amberlite XAD-7 resin $>$ Dowex-1 resin $>$ Adsorba $150 \mathrm{C}$ charcoal. With plasma, DHP-1 charcoal, Amberlite XAD-7 resin and Dowex-1 resin adsorbed similar amounts of SEA. During $4 \mathrm{~h}$ in-vitro perfusion of human plasma through the adsorbent columns, DHP-1 charcoal removed $50 \%$ of the initial amount of SEA, Adsorba $150 \mathrm{C}$ charcoal removed $8.1 \%$ of SEA and Amberlite XAD-7 resin removed $32.5 \%$ of SEA (fig. 3). When the binding capacities were determined directly from the amount of radioactivity bound to the adsorbents and expressed as the amount/g dry weight (table II),

Table I. Time course of distribution of SEA following a single i.v. injection of ${ }^{125} \mathrm{I}$-labelled SEA ( $\left.250 \mu \mathrm{g} / \mathrm{kg}\right)$ in rats

\begin{tabular}{|c|c|c|c|c|c|c|}
\hline \multirow{2}{*}{ Site } & \multicolumn{3}{|c|}{ Mean (SD) SEA $\mu \mathrm{g} / \mathrm{g}$ wet weight at } & \multicolumn{3}{|c|}{ Mean (SD) SEA $\mu \mathrm{g} /$ whole organ at } \\
\hline & $5 \mathrm{~min}$ & $30 \mathrm{~min}$ & $120 \mathrm{~min}$ & $5 \mathrm{~min}$ & $30 \mathrm{~min}$ & $120 \mathrm{~min}$ \\
\hline Liver & $0.71(0.11)$ & $0.43(0.05)$ & $0.34(0.03)$ & $8.07(2.09)$ & $4.05(0.15)$ & $2.90(0.21)$ \\
\hline Kidney & $2.60(0.34)$ & $13.00(1.5)$ & $16.87(1.06)$ & $4 \cdot 12(0 \cdot 48)$ & $17.96(0.46)$ & $9.79(1.25)$ \\
\hline Spleen & $0.49(0.01)$ & $1.48(0.04)$ & $1.23(0.06)$ & $0.32(0.04)$ & $0.96(0.10)$ & $0.78(0.05)$ \\
\hline Lung & $0.94(0.17)$ & $0.56(0.25)$ & $0.24(0.05)$ & $\ldots$ & ... & ... \\
\hline Intestine & $0.23(0.04)$ & $0.25(0.02)$ & $1 \cdot 17(0.26)$ & $\ldots$ & $\ldots$ & $\ldots$ \\
\hline Muscle & $0.07(0.02)$ & $0.10(0.04)$ & $0.08(0.02)$ & $\ldots$ & $\ldots$ & $\ldots$ \\
\hline Blood & $1.86(0.20)^{*}$ & $0.43(0.01)^{*}$ & $0.25(0.06)^{*}$ & $\ldots$ & $\ldots$ & $\ldots$ \\
\hline Urine & $\ldots$ & $1.20(0.05)^{*}$ & $2.02(0.17)^{*}$ & $\ldots$ & $\ldots$ & $\ldots$ \\
\hline
\end{tabular}

*Blood and urine values are $\mu \mathrm{g} / \mathrm{ml}$. 
a

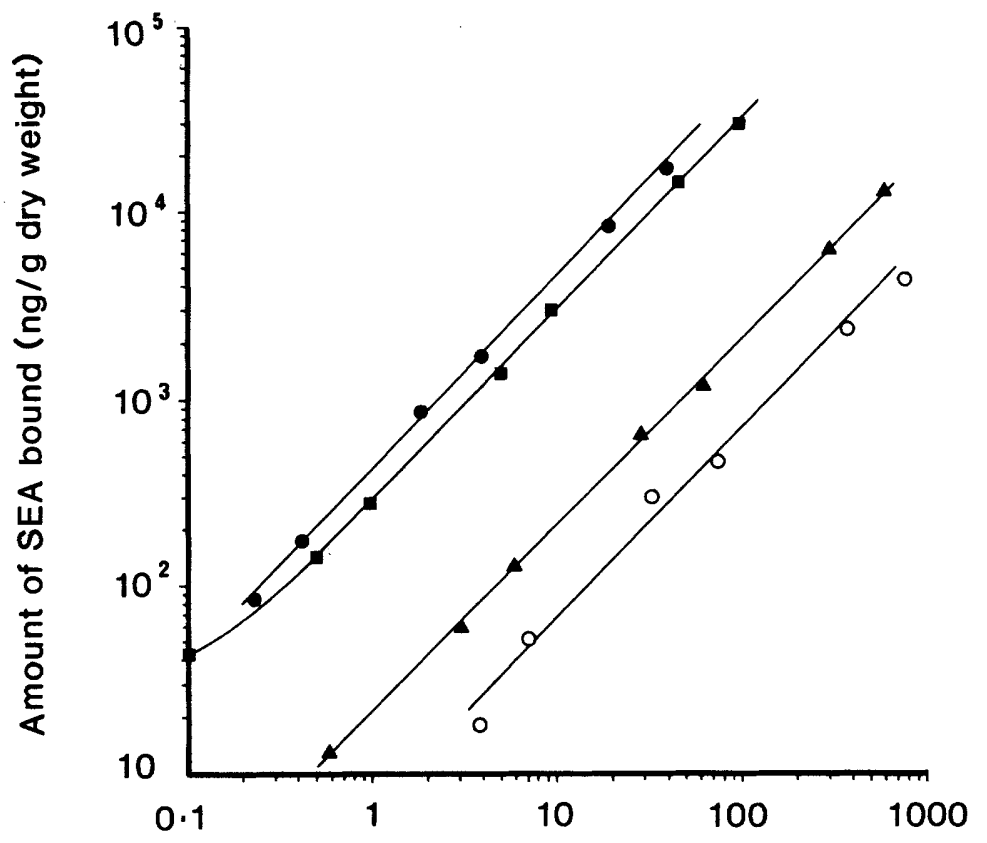

Final concentration of SEA $(\mathrm{ng} / \mathrm{ml})$

b

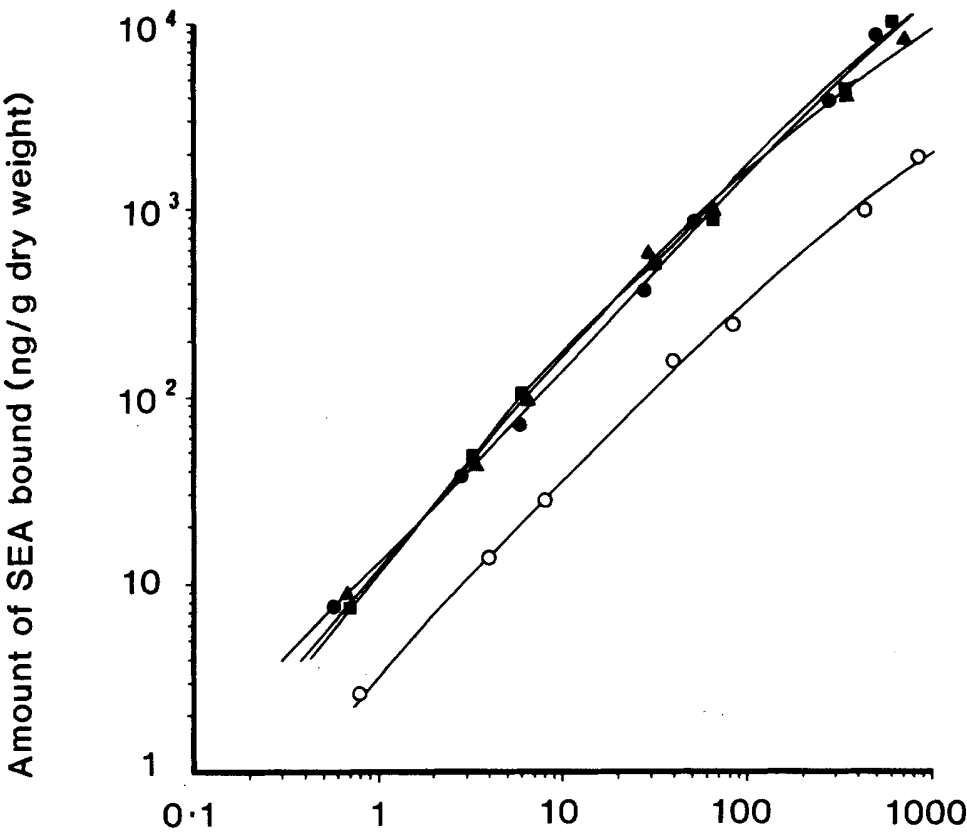

Final concentration of SEA $(\mathrm{ng} / \mathrm{ml})$

Fig. 2. Equilibrium adsorption isotherm of SEA to DHP-1 charcoal (O), Adsorba 150C charcoal (O), Amberlite XAD-7 resin ( $\square$ ) and Dowex-1 resin $(\boldsymbol{A})$ versus concentration of SEA remaining in solution at equilibrium; a, PBS supplemented with BSA $0 \cdot 1 \%$; b, human plasma.

Amberlite XAD-7 resin was better than DHP-1 charcoal. This reflected the lower dry weight of resin than charcoal in the column.

\section{Discussion}

This study has demonstrated that after i.v. injection of SEA the clearance from the vascular compartment is characterised by two markedly different phases. This biphasic clearance is characteristic of the pharmacokinetic behaviour of many proteins, ${ }^{20,21}$ reflecting first the rapid tissue uptake of SEA followed by the catabolism and excretion of SEA. Initially, ${ }^{125} \mathrm{I}-$ labelled SEA disappeared very rapidly from blood, having an average half-life of $3 \mathrm{~min}$, which is in agreement with reports that radio-iodinated SEB exhibited a half disappearance time of $2-4 \mathrm{~min}$ in rats ${ }^{22}$ and 5-9 min in monkeys. ${ }^{23}$ Similar results were obtained also by Melish et al. ${ }^{24}$ who measured the concentrations of TSST-1 in plasma of rabbits fol- 


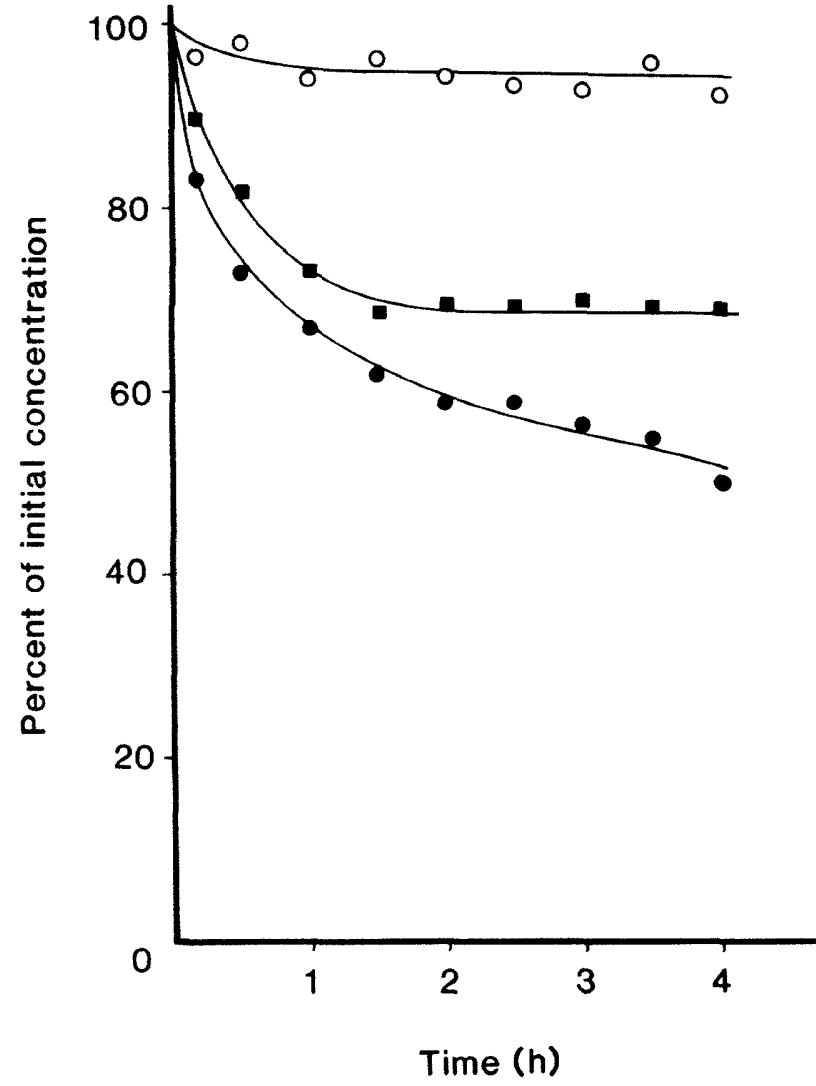

Fig. 3. Removal of SEA (initial concentration $100 \mathrm{ng} / \mathrm{ml}$ ) from $250 \mathrm{ml}$ of human plasma by columns containing DHP-1 charcoal (O), Adsorba 150C charcoal (O) or Amberlite XAD-7 resin ( $\square$ ) at a flow rate of $30 \mathrm{ml} / \mathrm{min}$. Percentages of SEA remaining unadsorbed in the inlet lines are shown. Each point represents the mean of two experiments.

Table II. Amount of SEA bound to charcoal and resin adsorbents during $4 \mathrm{~h}$ plasma perfusion

\begin{tabular}{lcc}
\hline Adsorbent & $\begin{array}{c}\text { Dry weight } \\
(\mathrm{g})\end{array}$ & $\begin{array}{c}\text { SEA bound, ng/g of } \\
\text { dry adsorbent* }\end{array}$ \\
\hline DHP-1 charcoal & $14 \cdot 2$ & $696 \cdot 5$ \\
Adsorba 150C charcoal & $12 \cdot 7$ & $165 \cdot 7$ \\
Amberlite resin & 6.4 & $940 \cdot 2$ \\
\hline
\end{tabular}

*Results are the mean of two experiments.

lowing i.v. bolus injection of $100 \mathrm{mg}$ of TSST-1. Examination of tissues containing ${ }^{125}$ I-SEA revealed that the kidney was the most important site of accumulation of SEA and that SEA was excreted mainly into urine, with some excretion into bile.

\section{References}

1. Marrack P, Kappler J. The staphylococcal enterotoxins and their relatives. Science $1990 ; \mathbf{2 4 8}$ : 705-711.

2. Dohlsten M, Hedlund G, Kalland T. Staphylococcal-enterotoxin-dependent cell-mediated cytotoxity. Immunol Today $1991 ; 12: 147-150$.

3. Bergdoll MS. Staphylococcal intoxications. In: Riemann $\mathbf{H}$, Bryan FL (eds) Food borne infections and intoxications. New York, Academic Press. 1979: 443-494.

4. Bergdoll MS, Crass BA, Reiser RF, Robbins RN, Dovis JP. A new staphylococcal enterotoxin, enterotoxin $F$, associated
Normann et al. ${ }^{22}$ showed that SEB was filtered easily by the glomerulus and was then rapidly and completely re-absorbed from the tubular urine by the cells of the proximal renal tubule. The importance of the kidney in removing these toxins from the blood has been demonstrated further by the finding that SEB disappeared from the blood at a slower rate when studies were conducted in nephrectomised monkeys or rats. ${ }^{25}$ The kidney has been shown previously to be an important site of accumulation and catabolism of other proteins including TNF- $\alpha,{ }^{21}$ IFN $-\alpha,{ }^{26}$ IFN- $\gamma,{ }^{27}$ and insulin. ${ }^{28}$ On the other hand, it has been reported that LPS (endotoxin) derived from gram-negative bacteria is taken up by the liver immediately after i.v. injection and is concentrated primarily in the Kupffer cells. ${ }^{29}$ However, this is probably because the molecular size of LPS (c. $\left.10^{6} \mathrm{da}\right)$ is too great for renal elimination.

Protection against the effects of staphylococcal enterotoxins in vivo can be provided by induction of an antibody response or by passive transfer of antibodies, although antibody protection could be overwhelmed by massive release of enterotoxins. ${ }^{23}$ As an alternative approach to this problem, direct removal of the toxins from the circulation may be of potential therapeutic value. Activated charcoal and Amberlite resin have been shown to have a large capacity for removing endogenous and exogenous toxins and have been used previously for clinical treatment of fulminant hepatic failure without serious adverse effects. ${ }^{30}$ The differences between binding of the various adsorbents in PBS solution and plasma indicate that SEA interacts with components of plasma. The in-vitro plasma perfusion experiments with small columns containing either charcoal or resin demonstrated that polyhemacoated activated charcoal and uncharged resin could remove a significant amount of SEA from human plasma. Use of these non-specific adsorbents also has the advantage that they remove a range of cytokines such as TNF- $\alpha$, IFN- $\gamma$, interleukin (IL)- 1 and IL- 6 at the same time, ${ }^{31}$ some of which can be induced by staphylococcal enterotoxins. If the columns were scaled up for clinical use, it would thus be possible to remove both SEA and the inflammatory mediators released in response to SEA at the same time.

We thank Dr H. Tranter and Ros Brehm, Biologics Division, Centre for Applied Microbiology and Research, PHLS, Porton Down for supplying the reagents and helpful advice. We also thank Dr Barbara McFarlane and Cynthia Bridger for help with the iodination of SEA and Immuno AG, Vienna for supporting H. M. K.

with toxic-shock syndrome Staphylococcus aureus isolates. Lancet 1981; 1: 1017-1021.

5. Melish ME, Glasgow LA. The staphylococcal scalded-skin syndrome. Development of an experimental model. N Engl J Med 1970; 282: 1114-1119.

6. Hodoval LF, Morris EL, Crowley GJ, Beisel WR. Pathogenesis of lethal shock after intravenous staphylococcal enterotoxin B in monkeys. Appl Microbiol 1968; 16: 187-192.

7. Marrack P, Blackman M, Kushnir E, Kappler J. The toxicity of staphylococcal enterotoxin $B$ in mice is mediated by $\mathrm{T}$ cells. J Exp Med 1990; 171 : 455-464.

8. Beisel WR. Pathophysiology of staphylococcal enterotoxin 
type B, (SEB) toxemia after intravenous administration to monkeys. Toxicon 1972; 10: 433-440.

9. Wakabayashi G, Gelfand JA, Jung WK, Connolly RJ, Burke JF, Dinarello CA. Staphylococcus epidermidis induces complement activation, tumor necrosis factor and interleukin-1, a shock-like state and tissue injury in rabbits without endotoxemia. J Clin Invest 1991; 87: 1925-1935.

10. Tracy KJ, Beutler B, Lowry SF et al. Shock and tissue injury induced by recombinant human cachectin. Science 1986; 234: 470-474.

11. Beutler B, Cerami A. Cachectin: more than a tumor necrosis factor. $N$ Engl J Med 1987; 316: 379-385.

12. Sugiyama H, Mckissic EM, Bergdoll MS, Heller B. Enhancement of bacterial enterotoxin lethality by staphylococcal enterotoxin. J Infect Dis $1964 ; 114$ : 111-118.

13. Fischer H, Dohlsten M, Lindvall M, Sjogren H-O, Carlsson R Binding of staphylococcal enterotoxin A to HLA-DR on B cell lines. J Immunol 1989; 142: 3151-3157.

14. Fraser JD. High affinity binding of staphylococcal enterotoxin A and B to HLA-DR. Nature 1989; 339: 221-223.

15. Peavy DL, Adler WH, Smith RT. The mitogenic effects of endotoxin and staphylococcal enterotoxin B on mouse spleen and human peripheral lymphocytes. $J$ Immunol $1970 ; 105$ : 1453-1458.

16. Langford MP, Stanton GJ, Johnson HM. Biological effects of staphylococcal enterotoxin A on human peripheral lymphocytes. Infect Immun 1978; 22: 62-68.

17. Dohlsten MG, Hedlund HO, Sjogren H-O, Carlsson R. Two subsets of human $\mathrm{CD} 4+\mathrm{T}$ helper cells differing in kinetics and capacities to produce interleukin 2 and interferongamma can be defined by the Leu-18 and UCHL1 monoclonal antibodies. Eur J Immunol 1988; 18: 11731178.

18. Miethke T, Wahl C, Heeg K, Echtenacher B, Krammer PH, Wagner $\mathrm{H}$. T cell-mediated lethal shock triggered in mice by the superantigen staphylococcal enterotoxin B: critical role of tumor necrosis factor. J Exp Med 1992; 175: 91-98.

19. David GS, Reisfeld RA. Protein iodination with solid state lactoperoxidase. Biochemistry 1974; 13: 1014-1021.
20. Verstraete M, Bounameaux H, deCok F, Van de Werf F, Collen D. Pharmacokinetics and systemic fibrinogenolytic effects of recombinant human tissue-type plasminogen activator (rt-PA) in humans. $J$ Pharmacol Exp Ther 1985; 235: 506-512.

21. Ferraiolo BL, Moore JA, Crase D, Gribling P, Wilking H, Baughman RA. Pharmacokinetics and tissue distribution of recombinant human tumor necrosis factor-a in mice. Drug Metab Dispos 1988; 16: 270-275.

22. Normann SJ, Jaeger RF, Johnsey RH. Pathology of experimental enterotoxemia. The in vivo localization of staphylococcal enterotoxin B. Lab Invest 1969; 20: 17-25.

23. Rapoport MI, Hodoval LF, McGann G, Grogan EW, Beisel WR. The influence of specific antibody on the disappearance of staphylococcal enterotoxin B from blood. $J$ Clin Invest 1966; 45: 1365-1372.

24. Melish ME, Murata S, Fukunaga C, Frogner K, Hirata S, Wong C. Endotoxin is not an essential mediator in toxic shock syndrome. Rev Infect Dis 1989; 11 Suppl 1: S219-S230.

25. Staab EV, Niederhuber J, Rhoda DA, Faulkner CS, Beisel WR. Role of the kidney in staphylococcal enterotoxemia. Appl Microbiol 1969; 17: 394-398.

26. Bocci V, Pacini A, Muscettola $M$ et al. Renal filtration, absorption and catabolism of human alpha interferon. $J$ Interferon Res 1981; 1: 347-352.

27. Bocci V, Pacini A, Pessina GP, Paulesu L, Muscettola M, Lunghetti G. Catabolic sites of human interferon-gamma. J Gen Virol 1985; 66: 887-891.

28. Chamberlain MJ, Stimmler L. Renal handling of insulin. J Clin Invest 1967; 46: 911-919.

29. Mathison JC, Ulevitch RJ. The clearance, tissue distribution, and cellular localization of intravenously injected lipopolysaccharide in rabbits. J Immunol 1979; 123: 2133-2143.

30. Hughes RD, Williams R. Clinical experience with charcoal and resin haemoperfusion in fulminant hepatic failure. Semin Liver Dis 1986; 6: 164-173.

31. Nagaki M, Hughes RD, Lau JYN, Williams R. Removal of endotoxin and cytokines by adsorbents and the effect of plasma protein binding. Int J Artif Organs 1991 ; 14: 43-50. 